University of Nebraska - Lincoln

DigitalCommons@University of Nebraska - Lincoln

Faculty Publications: Department of Entomology

Entomology, Department of

1997

\title{
Seasonal Occurrence of Rice Yellow Mottle Virus in Lowland Rice in Côte d'Ivoire
}

\author{
E. A. Heinrichs
}

A. A. Sy

S. K. Akator

I. Oyediran

Follow this and additional works at: https://digitalcommons.unl.edu/entomologyfacpub

Part of the Agriculture Commons, Agronomy and Crop Sciences Commons, Entomology Commons, and the Plant Pathology Commons

This Article is brought to you for free and open access by the Entomology, Department of at DigitalCommons@University of Nebraska - Lincoln. It has been accepted for inclusion in Faculty Publications: Department of Entomology by an authorized administrator of DigitalCommons@University of Nebraska - Lincoln. 
Published in International Journal of Pest Management 43:4 (1997), pp. 291-297;

doi: 10.1080/096708797228591

Copyright (C) 1997 Taylor \& Francis Ltd. Used by permission.

Published online November 26, 2010.

\title{
Seasonal Occurrence of Rice Yellow Mottle Virus in Lowland Rice in Côte d'Ivoire
}

\author{
E. A. Heinrichs, A. A. Sy, S. K. Akator, and I. Oyediran
}

West Africa Rice Development Association, B. P. 2551, Bouaké, Côte d'Ivoire, West Africa

\begin{abstract}
Monthly plantings of the rice variety Bouaké 189 were made under lowland irrigated conditions, to obtain information on the phenological and seasonal occurrence of pests and diseases on the West African Rice Development Association (WARDA) research farm near Bouaké, Côte d'Ivoire. Regular sampling of insect pests and observations on rice yellow mottle virus (RYMV) disease infection throughout the year provided information on the occurrence of RYMV and potential insect vectors. RYMV incidence and grain yields varied depending on planting date, and for a given planting date, varied from one year to another. There was no evidence that RYMV incidence increases in successive seasons under continuous cropping. There was no significant correlation between RYMV incidence and either rainfall or wind speed. Leaf feeding damage by the beetle vector of RYMV, Trichispa sericea Guerin-Meneville (Coleoptera: Chrysomelidae), and percentage RYMV infected plants were severe in the July and August plantings in 1993, but whereas T. sericea was not observed thereafter, RYMV spread continued. The white leafhoppers Cofana spectra (Distant) and C. unimaculata (Signoret) (Hemiptera: Cicadellidae), the green leafhoppers Nephotettix spp. (Hemiptera: Cicadellidae), the spittle bug Locris rubra F. (Hemiptera: Cercopidae), the diopsids Diopsis longicornis Macquart and D. apicalis Dalman (Diptera: Diopsidae), and the grasshopper Oxy hyla Stål (Orthoptera: Acridadae) were the most abundant of the insect pests and had distinct population peaks within a year. However, population abundances were not correlated with RYMV incidence. The variability of RYMV in time and space and the potential role of weeds as alternative hosts for RYMV are discussed.
\end{abstract}

Keywords: Côte d'Ivoire, Oryza sativa L., rice insect pests, rice yellow mottle virus disease, seasonal occurrence, West Africa 


\section{Introduction}

Rice yellow mottle virus (RYMV) disease was first isolated by Bakker (1974) from the rice cultivar "Sindano" collected from a rice field near Kisumu, Kenya, along the shore of Lake Victoria. He proposed the name rice yellow mottle disease and named the causal agent rice yellow mottle virus (RYMV). RYMV was shown to be mechanically transmitted and belongs to the genus Sobemovirus (Bakker, 1970).

Bakker (1974) described the characteristic symptoms caused by RYMV. Discoloration is observed about 2-3 weeks after transplanting; leaves are yellowish (Sindano), mild green (Basmati 217), or orange (IR 8), depending on the rice variety. Although diseased plants usually survive, they are severely stunted, they produce fewer tillers, flowering is delayed, there is an incomplete emergence of panicles, and grains are unfilled and discolored (Bakker, 1974; IITA, 1982, 1985). The effect of RYMV on rice grain yield depends on the time of infection and the rice variety (Bakker, 1974). Natural infection of IR 65 in mangrove swamps in Sierra Leone resulted in 17\% stunting, a 72\% increase in spikelet sterility, a $66 \%$ increase in grain discoloration, and an $82 \%$ reduction in yield (Taylor et al., 1990). In screenhouse experiments at WARDA, grain yields of artificially inoculated susceptible varieties Bouaké 189 and BG90-2 were reduced by $84 \%$ and 67\% respectively (Sy and Alluri, 1993).

After RYMV was first reported from Kenya (Bakker, 1970), it was shortly thereafter reported from Sierra Leone (Raymundo and Buddenhagen, 1976); Côte d'Ivoire (Fauquet and Thouvenel, 1977); Nigeria (IITA, 1978); Tanzania, Zanzibar, and Liberia (Buddenhagen and Rossel, in Rossel et al., 1982); Burkina Faso and Mali (John et al., 1984); Niger (Reckhaus and Adamou, 1986); and Guinea (Fomba, 1990). In Mali, severe infection was observed in the Office du Niger irrigation project area in 1994 (WARDA, 1994).

RYMV is most commonly found in lowland irrigated rice but was also reported in mangrove and inland swamps in Guinea during 1982-1986 (Fomba, 1990) and in upland rice in Sierra Leone during 1987 and in Côte d'Ivoire in 1985 (Awoderu et al., 1987). Screening for resistance to RYMV at IITA (1982) indicated that all Oryza glaberrima Steud. and most upland cultivars tested were tolerant, whereas most irrigated lowland cultivars were susceptible.

The most severe outbreaks of RYMV have occurred in lowland cultivars introduced from Asia while local cultivars have been less severely affected (Thresh, 1991). Bouaké 189, a cultivar introduced from the Philippines, is widely grown in Côte d'Ivoire and is highly susceptible to RYMV. In 1994 in Mali, the susceptible cultivar, BG90-2 from Sri Lanka, was grown over $90 \%$ of the Office du Niger area and was severely infested (WARDA, 1994).

Increasing incidence of RYMV in Africa appears to be associated with a change in cropping practices, especially a change from one crop to two crops per year. In Surinam the impact of double-cropping was apparent on hoja blanca vector, Tagosodes orizicolus (Muir) (Hemiptera: Delphacidae) populations (van Hoof et al., 1962). The area of the first recorded outbreak of RYMV in Africa was associated with a newly developed irrigation project that provided water for sequential plantings throughout the year (Bakker, 1974; Thresh, 1989). Similar conditions are suggested to be responsible for an outbreak in southeastern Nigeria in the early 1980s (Rossel et al., 1982). 
Bakker (1974) cited a number of plant species which proved to be systemic hosts of RYMV in laboratory tests. Among these were several species of wild rice Oryza. The grasses Dinebra retroflexa (Vahl) Panz., Eleusine indica (L.), and Eragrostis tenuifolia (A. Rich) Steud. were reported as potential alternative hosts of RYMV at the Ahero and West Kano Irrigation Scheme in Kenya (Okioma et al., 1983). In valley bottoms, in Sierra Leone, volunteer rice and ratoons from previously harvested crops favor survival of the virus during the offseason (Fomba, 1988). Fomba also successfully transmitted RYMV to Eleusine indica and Echinochloa crus-galli (L.) at Rokupr. RYMV symptoms have been observed on Echinochloa colona (L.) on roads and irrigation ditches bordering lowland paddies on the WARDA M'bé research station (Johnson, Heinrichs and Sy, unpublished). Plants of O. longistaminata, A. Chev. \& Roehr, a wild perennial species of rhizomatous rice, exhibited the typical symptoms of RYMV infection and reacted positively to the RYMV antiserum (John et al., 1984). It was surmised that $O$. longistaminata may have been the original wild host for RYMV.

Bakker's $(1971,1974)$ pioneering studies on the transmission of RYMV in Kenya continue to be the pivotal work on the subject. Of the numerous insect species tested, only the chrysomelid beetles (Coleoptera: Chrysomelidae) genus near Apophylia, Oulema dunbrodiensis Jac., Monolepta flaveola Gerst., M. irregularis Rits., Sesselia pusilla Gerst., Chaetocnema abyssinica Jac., C. pulla Chapuis, Dactylispa bayoni Gestro, Dicladispa paucispina (Weise), D. viridicyanea (Kraatz) and Trichispa sericea Guerin-Meneville, and the long-horned grasshopper Conocephalus merumontanus Sjöstedt (Orthoptera: Tettigoniidae) were vectors. The short-horned grasshopper, Oxya spp. (Orthoptera: Acrididae) is also reported to be an RYMV vector (IRRI, 1983). Of these species, Chaetocnema pulla, Dactylispa bayoni, Dicladispa viridicyanea, Trichispa sericea, and Oxya hyla Stål occur in West Africa. Severe RYMV infections in the rice cultivar Bouaké 189, at Sakassou, Côte d'Ivoire, were associated with high Trichispa sericea populations (WARDA, 1993).

RYMV has been observed on the WARDA research farm at M'bé since lowland experiments began in 1992. In 1993 a study was initiated to determine the phenological and seasonal occurrence of pests on the farm. The objective was to use the information as a guide in selecting planting dates for experiments to either minimize or maximize the abundance of pests. This paper reports on the seasonal occurrence of RYMV and potential insect vectors and the effect of RYMV on rice grain yield.

\section{Methods}

A "rice garden" approach with monthly plantings is being used to determine the seasonal abundance of various insect species and the severity and percent incidence of RYMV-infected rice plants. Two rice gardens, separated by about $1 \mathrm{~km}$ were established in a lowland area on the M'bé research station near Bouaké, Côte d'Ivoire. The rainy season at the study site is May to October, and the dry season is November to April. The "harmattan" and coldest months of the year occur during January-February.

Monthly plantings were initiated in April 1993. On the 7th day of every month three plots (replicates) measuring $7 \mathrm{~m} \times 14 \mathrm{~m}$ are planted in a randomized complete block design with 21 day-old seedlings of the cultivar Bouaké 189 at a hill spacing of $25 \mathrm{~cm} \times 25 \mathrm{~cm}$. Fertilizer (in the form of NPK 10-18-10) is incorporated into the soil at the rate of $150 \mathrm{~kg} / \mathrm{ha}$ 
at transplanting. Urea at $75 \mathrm{~kg} / \mathrm{ha}$ is broadcast at 30 and 60 days after transplanting (DT) and plots are hand weeded as necessary.

Insect populations are determined by taking 50 sweeps with a sweep net per plot at fortnightly intervals from the 2nd to the 12th week after transplanting. Both the severity of RYMV infection, and the percentage of plants infected, are determined at 21,51, and 81 DT. Severity and percent plants with RYMV symptoms are determined by observing all of the plants of three rows per plot (216 hills). Severity is based on the IRR (1988) "Standard Evaluation System for Rice" with a scale of $1-9$ where $1=$ no symptoms and $9=$ severe damage. Agar-gel diffusion tests are conducted on plants with symptoms to verify the presence of RYMV.

The second rice garden was established in May 1994. Treatments consist of monthly plantings and fertilizer applications. As in the first rice garden, transplanting of cultivar Bouaké 189 occurs on the 7 th day of each month. Plot size is $7 \mathrm{~m} \times 8 \mathrm{~m}$ and treatments are replicated four times. Paired plots, with and without fertilizer, are planted next to each other. The fertilizer treatment consists of a basal application of triple super phosphate (TSP) at $90 \mathrm{~kg} / \mathrm{ha}$ and $150 \mathrm{~kg} / \mathrm{ha}$ NPK $(10-18-10)$ at transplanting and $50 \mathrm{~kg} / \mathrm{ha}$ urea $(45 \%$ $\mathrm{N})$ at 30 and $60 \mathrm{DT}$. Insect populations and damage and RYMV severity and percent plants with RYMV symptoms are recorded as in the first rice garden. Wind speed and rainfall are recorded daily. Mean comparisons of the plots with and without nitrogen fertilizer were made according to the least significant difference (LSD) method of Fisher (1935).

\section{Results}

Grain yields in rice garden 1 as affected by month of planting for the two years May-April 1993-1994 and 1994-1995 are shown in Figure 1. Grain yields were extremely variable from one month to another. There is little relationship between the two years as $r=-0.37(n=36$, ns). Major yield constraints in the May, July, and August 1993 and March 1994 plantings were damage by the insect Trichispa sericea and/or RYMV. In July 1993 yield was only 750 $\mathrm{kg} / \mathrm{ha}$. Low yields in the October and November 1993 plantings are believed to be due, at least partially, to cold temperatures and winds at flowering, during the January/February "harmattan" period. Since August 1993, T. sericea populations have been extremely low.

Percentage plants observed with RYMV symptoms increased with the age of the crop and was highest at 81 DT as compared to the 21 and 51 DT observations (Figure 2). Percentage of rice plants infected with RYMV for the May 1994 to April 1995 year in rice garden 1 was highest (20\%) in the May and June plantings. Less than $5 \%$ of the plants in the July, August, October, November, and December plantings were infected. Except for the May, June, and October plantings, no RYMV symptoms were observed at 21 DT. RYMV severity ratings were also highest for the May and June plantings and were the highest at 81 DT. 


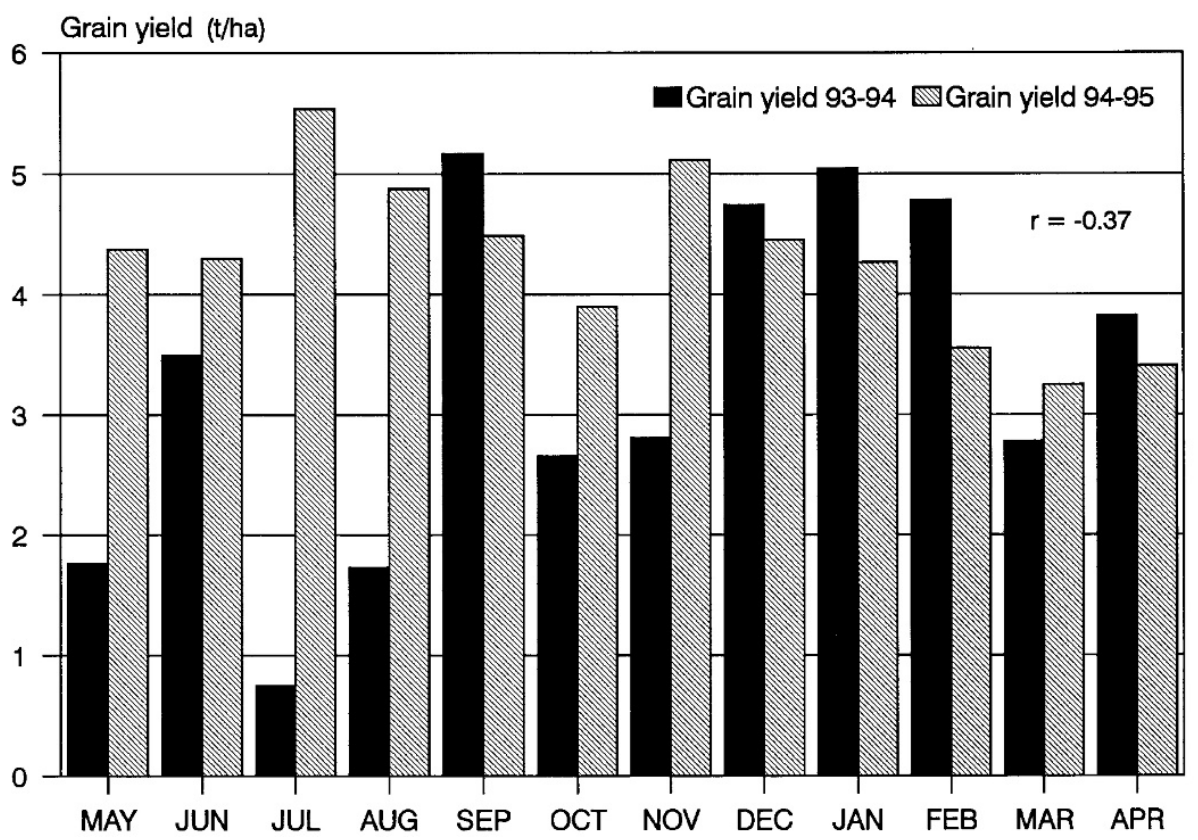

Figure 1. Grain yield of rice cultivar Bouaké 189 for monthly plantings from May 1993 to April 1994 (solid columns) and May 1994 to April 1995 (hatched columns). The relationship between the two years in grain yield was negatively correlated $(\mathrm{r}=-0.37)$ (nonsignificant, $P \geq 0.05$ ). Rice garden 1 , WARDA, Bouaké, Côte d'Ivoire.

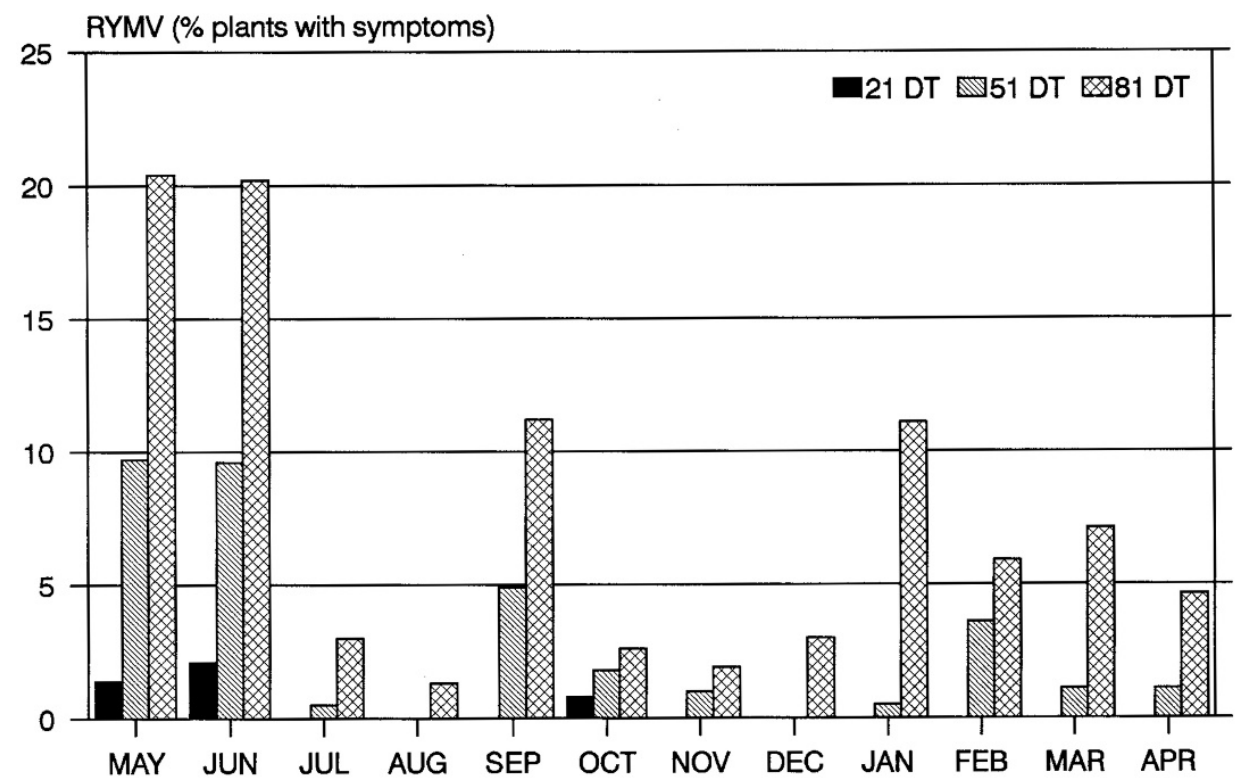

Figure 2. Percentage of rice cultivar Bouaké 189 plants with RYMV symptoms at 21, 51, and 81 days after transplanting (DT) for monthly plantings from May 1994 to April 1995. Rice garden 1, WARDA, Bouaké, Côte d'Ivoire. 
The relationship between grain yields and percentage of plants infected with RYMV is indicated in Figure 3. Grain yields varied from 3.3 to $5.5 \mathrm{t} / \mathrm{ha}$. Highest yields were observed in the July, August, September, November, and December 1995 plantings when RYMV infection was low. The correlation between yield and RYMV infection was low $(r=-0.07$, $n=48, \mathrm{~ns}$ ) indicating that factors other than RYMV were also affecting yield. Correlations between RYMV and the weather factors, rainfall, and wind speed were run. For both rice gardens, the correlations between RYMV and rainfall for the periods of 30 and 60 DT were less than $r=-0.18(n=12$, ns). Correlations between RYMV and wind speed for the same periods ranged from $r=-0.01$ to $r=0.33$ and were also nonsignificant $(n=12)$.

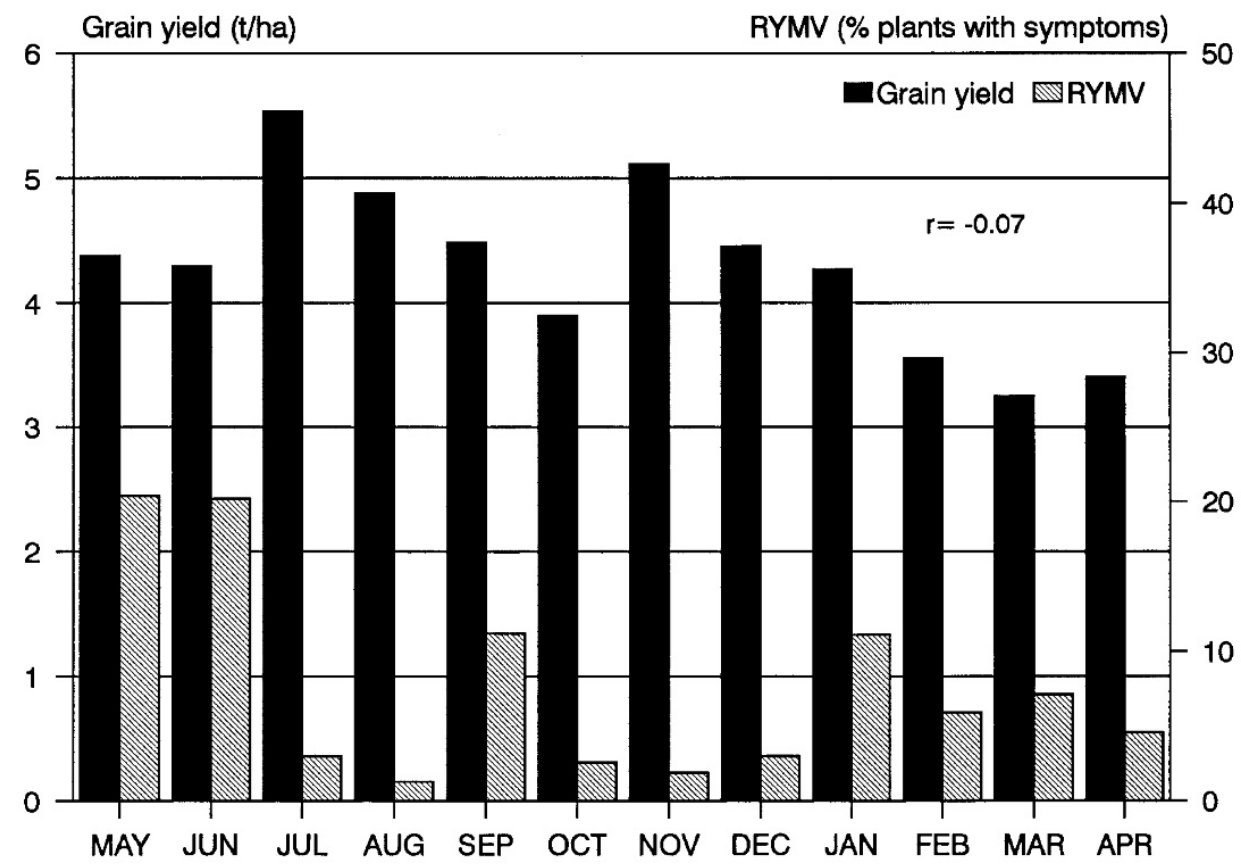

Figure 3. Grain yield and percentage of rice cultivar Bouaké 189 plants with RYMV symptoms at 81 days after transplanting for monthly plantings from May 1994 to April 1995. The relationship between grain yield and percentage plants with RYMV symptoms was negatively correlated $(r=-0.07)$ (nonsignificant, $P \geq 0.05$ ). Rice garden 1 , WARDA, Bouaké, Côte d'Ivoire.

In comparing the percentage of plants with RYMV symptoms for the two years, May to April 1993-1994 versus 1994-1995, it is evident that there is a distinct difference in infection from one year to another in the same field as indicated by the lack of significant correlation between the two years (Figure 4) $(r=0.13, n=24$, ns). In 1993-1994, infected plants were more than 20\% in August to November plantings, while in 1994-1995 infection surpassed 10\% in only May, September, and January. In November 1993 the infection was $47 \%$ while in November 1994 it was only 7\%. 


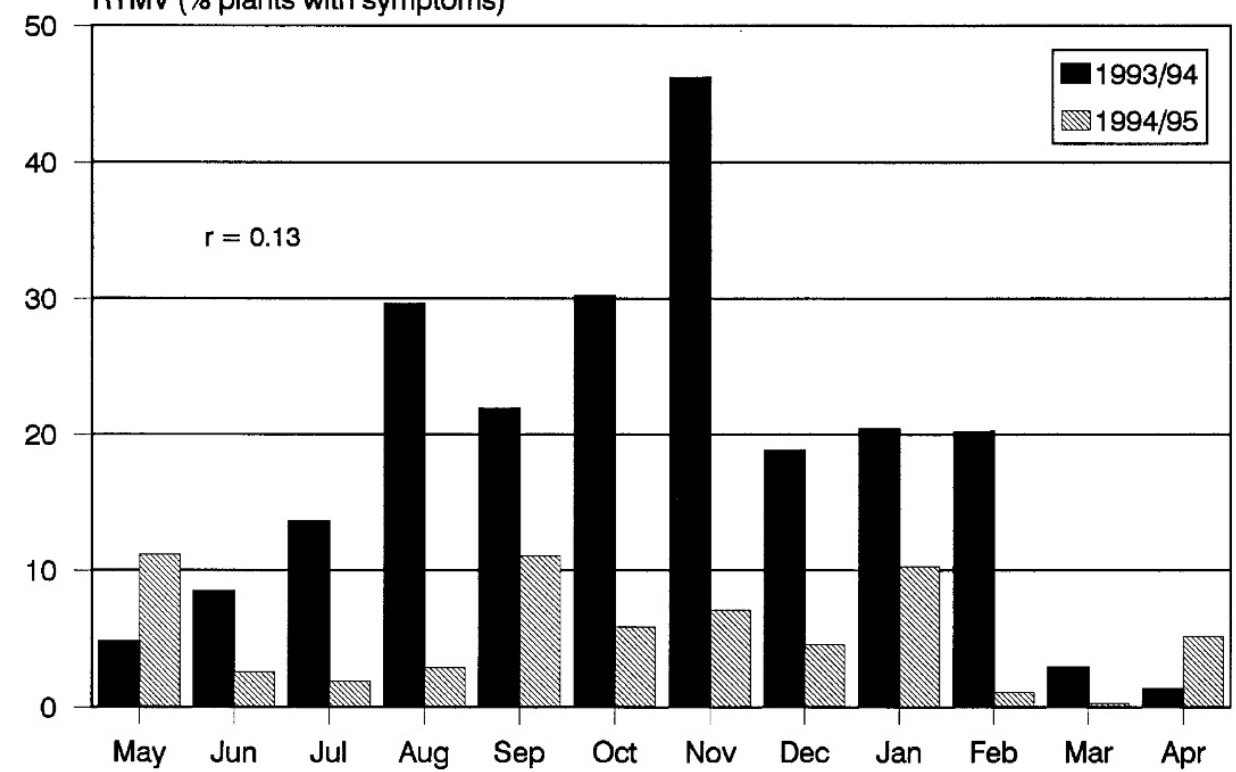

Figure 4. Percentage of rice cultivar Bouaké 189 plants with RYMV symptoms at 81 days after transplanting, as affected by month of transplanting in the years 1993-1994 and 1994-1995. The relationship between the two years in percentage plants with RYMV symptoms was positively correlated $(r=0.13)$ (nonsignificant, $P \geq 0.05)$. Rice garden 1 , WARDA, Bouaké, Côte d'Ivoire.

In rice garden 1 there was also a distinct difference between replicates of the same planting date in the percentage of plants with RYMV symptoms. This difference was especially evident in the December 1993 to March 1994 plantings where plants with symptoms varied by as much as $44 \%$ between replications. In rice garden 2, percentage of plants with RYMV symptoms in May 1994 to April 1995 plantings was not affected by the level of nitrogen application (Figure 5). Mean comparisons of the two nitrogen treatments, made according to the least significant difference method of Fisher (1935), indicate no significance among treatments $(F=3.2, p=0.004)$. Percentage of plants with symptoms was highest in the January to April plantings and reached $30 \%$ in the April planting with nitrogen. RYMV severity ratings were also highest in the January to April plantings.

In comparing the two rice gardens for the percentage of plants with RYMV symptoms, it is evident that there is no agreement between the two $(r=-0.23, n=12$, ns) (Figure 6). Infection in rice garden 1 was highest in May and June plantings while those months were among the lowest for rice garden 2. In the April planting, 30\% of the plants had RYMV symptoms in rice garden 2 but less than $5 \%$ of the plants in rice garden 1 had symptoms. 


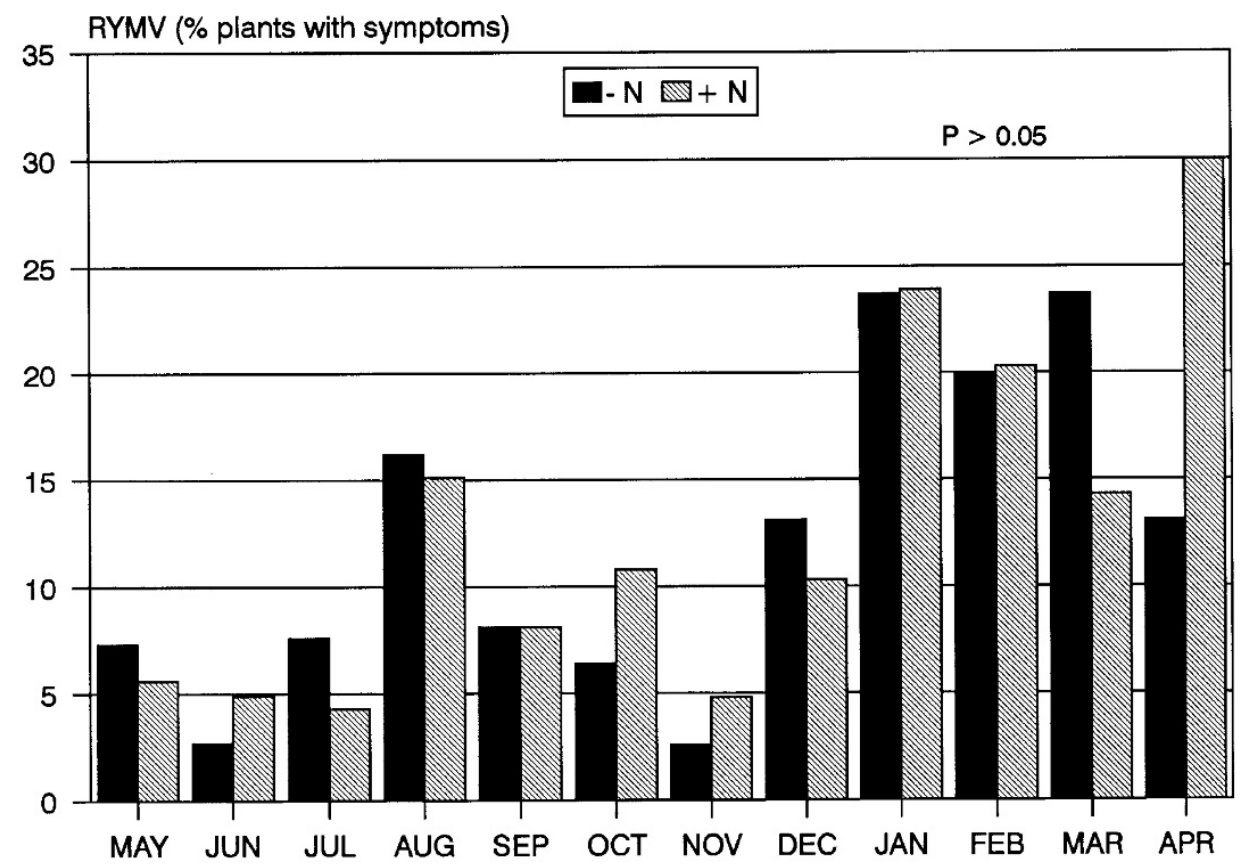

Figure 5. Percentage of rice cultivar Bouaké 189 plants with RYMV symptoms at 81 days after transplanting, as affected by month of transplanting and nitrogen application from May 1994 to April 1995. The least significant difference method of Fisher (1935) indicated no significant difference between nitrogen treatments $(P \geq 0.05)$. Rice garden 2, WARDA, Bouaké, Côte d'Ivoire.

The relationship between the individual population of suspect insect vectors and RYMV infection in rice garden 1 from May 1994 to April 1995 was determined for several insect species including the white leafhoppers Cofana spectra and C. unimaculata, green leafhoppers Nephotettix spp., the spittle bug Locris rubra F., the stalk-eyed flies Diopsis longicornis and D. apicalis, and the grasshopper Oxya hyla. Both the Cofana spectra and C. unimaculata populations were highest in the November planting while the percentage of RYMV infected plants was low for that planting (Figure 6). The Nephotettix population was highest in August when RYMV was the lowest for the year. Locris rubra populations peaked in October and November, two very low months for RYMV, whereas L. rubra populations were low in May and June when RYMV infection was highest. Both Diopsis species were abundant throughout the year, being high in November, when RYMV was low, and low in May and June, when RYMV was high. The grasshopper Oxya hyla population was highest in October when RYMV was low, and lowest in June, when RYMV was high. 


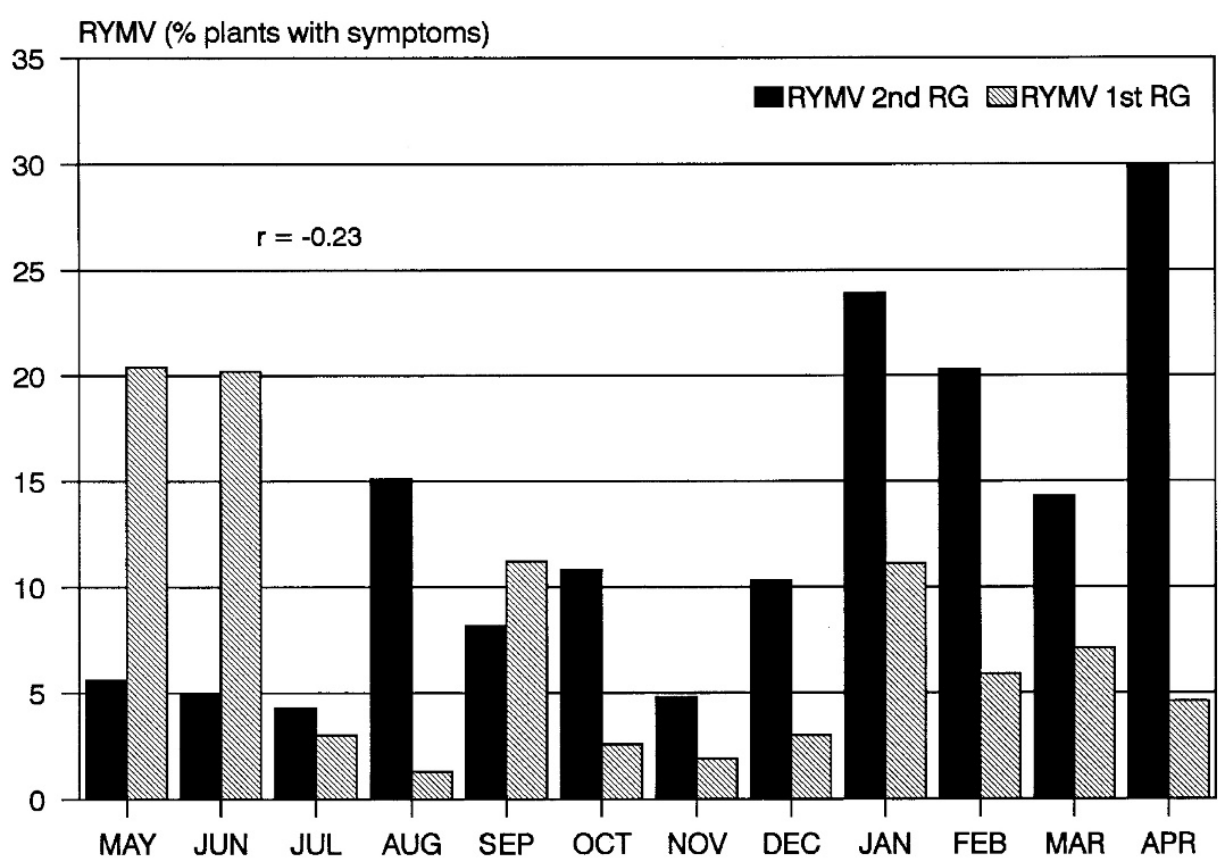

Figure 6. Percentage of rice cultivar Bouaké 189 plants infected with RYMV symptoms at 81 days after transplanting, in the 1st (hatched) and 2nd (solid) rice garden (RG), as affected by month of transplanting from May 1994 to April 1995. The relationship between the two rice gardens in percentage of plants with RYMV symptoms was negatively correlated $(r=-0.23)$ (nonsignificant, $P=40.05)$. WARDA, Bouaké, Côte d'Ivoire.

\section{Discussion}

When populations of the known beetle vector Trichispa sericea were high, in May to June plantings in a 1993-1994 study, RYMV was also high. However, Trichispa sericea has not been detected in either of the rice gardens since August 1993, but RYMV infection has, although less than in 1993. Other vectors such as Chaetocnema spp. reported by Bakker (1974) have not been abundant. It appears that there are additional vectors at WARDA or that the RYMV is transmitted by means in addition to insect vectors. It is also possible that, despite the absence of a positive correlation between the populations of the insect species collected in the study and percentage RYMV infection, even the low insect populations may be sufficient to transmit RYMV and that the variability in RYMV from month to month may be due to a variation in time in the ability of the insect species to transmit the virus.

It seems logical to expect that the RYMV infection will move from infected plants in older plots to younger plants in later planted adjacent plots resulting in a continuous buildup of the inoculum with time. However, it is interesting to note that there has been no increasing trend of RYMV infection with time in either of the rice gardens. Infection was extremely high in rice garden 1 during the first planting months but decreased thereafter and has since fluctuated. 
Although percentage of RYMV-infected ratoon plants (growth from stubbles after harvesting), as based on damage symptoms, is usually at least twice that of the main crop, there is no evidence that ploughing the infected stubble into the soil has any effect on the RYMV infection of the subsequent crop. Thus soil and water transmission, from the decaying infected stubble, does not appear likely.

Nitrogen application had no effect on RYMV infection. This may be due to a high level of naturally occurring nitrogen in these plots, as was evident in satisfactory growth of the plants and yield.

For several planting dates there were distinct differences in the level of RYMV infection between the two rice gardens and also between replications within the same rice garden. Seedlings were all grown in the same nursery and handled the same way during transplanting, suggesting that differences in RYMV in the two rice gardens, and among plots in the same rice garden, must be due to some location-related factor. We have observed that RYMV-infected Echinochloa colona plants were most abundant on the roadside and irrigation canals surrounding rice garden 1 during the rainy season, July to October. However, RYMV infection in rice was not high during this period (Figure 6). Further, the lack of a clear relationship between the level of RYMV infection and the presence of adjacent, older RYMV-infected rice plants indicates that the proximity of inoculum may not be a major factor in the spread of RYMV.

Based on the results obtained in this study it is evident that the extent of RYMV is highly variable in space and time. This is indicated by the differences in RYMV infection between the two rice gardens and by the lack of a relationship in RYMV infection for the monthly planting dates from one year to another. Continued studies are necessary to determine the mode of RYMV transmission and to identify the various ecological factors affecting the severity of RYMV incidence in West Africa.

\section{References}

Awoderu, V. A., Alam, M. S., Thottapilly, G. and Allluri, K., 1987. Outbreaks and new records. Ivory Coast. Rice yellow mottle virus in upland rice. FAO Plant Protection Bulletin, 35, 32-33.

Bakker, W., 1970. Rice yellow mottle, a mechanically transmissible virus disease of rice in Kenya. Netherlands Journal of Plant Pathology, 76, 53-63.

Bakker, W., 1971. Three new beetle vectors of rice yellow mottle virus in Kenya. Netherlands Journal of Plant Pathology, 77, 201-206.

Bakker, W., 1974. Characterization and ecological aspects rice yellow mottle virus in Kenya. Agricultural Research Reports 829 (Wageningen, Netherlands: Centre for Agricultural Publishing and Documentation).

Fauquet, C. and Thouvenel, J. C., 1977. Isolation of the rice yellow mottle virus in the Ivory Coast. Plant Disease Reporter, 61, 443-446.

Fisher, R. A., 1935. The Design of Experiments (Edinburgh: Oliver and Boyd).

Fomba, S. N., 1988. Screening for seedling resistance to rice yellow mottle virus in some rice cultivars in Sierra Leone. Plant Disease, 72, 641-642.

Fomba, S. N., 1990. Rice yellow mottle virus (RYMV) on swamp rice in Guinea. International Rice Research Newsletter, 15(6), 21. 
IITA (International Institute of Tropical Agriculture), 1978. Annual Report for 1977 (Ibadan, Nigeria: International Institute of Tropical Agriculture), pp. 20-21.

IITA (International Institute of Tropical Agriculture), 1982. Rice yellow mottle virus. Annual Report 1982 (Ibadan, Nigeria: International Institute of Tropical Agriculture), pp. 16-17.

IITA (International Institute of Tropical Agriculture), 1985. Strategies to combat yellow mottle virus disease in upland and lowland rice. Annual Report and Research Highlights (Ibadan, Nigeria: International Institute of Tropical Agriculture) pp. 96-97.

IRRI (International Rice Research Institute), 1983. Field Problems of Tropical Rice, Revised edition, Los Banos, Philippines: IRRI.

IRRI (International Rice Research Institute), 1988. Standard Evaluation System for Rice, 3rd edition, Los Banos, Philippines: IRRI.

John, V. T., Thottapilly, G. and Awoderu, V. A., 1984. Occurrence of rice yellow mottle virus in some Sahelian countries in West Africa. FAO Plant Protection Bulletin, 32, 86-87.

Okioma, S. N. M., Mulchoki, R. N. and Gathuru, E. M., 1983. Alternate hosts of rice yellow mottle virus in the Lake Victoria basin of Kenya. Tropical Pest Management, 29, 295-296.

Raymundo, S. A. and Buddenhagen, I. W., 1976. A virus disease in West Africa. International Rice Commission Newsletter, 25(1/2), 58.

Reckhaus, P. M. and Adamou, I., 1986. Rice diseases and their economic importance in Niger. FAO Plant Protection Bulletin, 34, 77-82.

Rossel, H. W., Thottapilly, G. and Buddenhagen, I. W., 1982. Occurrence of rice yellow mottle virus in two important rice-growing areas of Nigeria. FAO Plant Protection Bulletin, 30, 137-139.

Sy, A. A. and Alluri, K., 1993. Selection of RYMV-resistant cultivars and estimation of RYMV-induced yield loss under natural and artificial pressure. WARDA Annual Report, (Bouaké, Côte d'Ivoire), West Africa Rice Development Association, pp. 44-45.

Taylor, D. R., Fofie, A. S. and Suma, M., 1990. Natural infection of rice yellow mottle virus disease (RYMV) on rice in Sierra Leone. International Rice Research Newsletter, 15 (5), 19.

Thresh, J. M., 1989. Insect-borne viruses of rice and the green revolution. Tropical Pest Management, $35,264-272$.

Thresh, J. M., 1991. The ecology of tropical plant viruses. Plant Pathology, 40, 324-339.

Van Hoof, H. A., Stubbs, R. W. and Wouters, L., 1962. Beschouwingen over hoja blanca en zijn overbrenger Sogata orizicola Muir. Surinaamse Landbouw, 10, 3-18.

WARDA (West Africa Rice Development Association), 1993. Report of the multidisciplinary task force monitoring tour to the Republics of Côte d'Ivoire and Ghana. WARDA Task Force Meetings Series 32 (Bouaké, Côte d'Ivoire: WARDA).

WARDA (West Africa Rice Development Association), 1994. Special RYMV monitoring tour to Mali. WARDA Task Force Meetings Series (Bouaké, Côte d'Ivoire: WARDA). 